Article

\title{
Lignan Glycosides and Flavonoid Glycosides from the Aerial Portion of Lespedeza cuneata and Their Biological Evaluations
}

\author{
Jiwon Baek ${ }^{1}$, Tae Kyoung Lee ${ }^{1}$, Jae-Hyoung Song ${ }^{2}$, Eunyong Choi ${ }^{3}$, Hyun-Jeong Ko ${ }^{2}$, \\ Sanghyun Lee ${ }^{4}$, Sang Un Choi ${ }^{5}$, Seong Lee ${ }^{6}$, Sang-Woo Yoo ${ }^{7}$, Seon-Hee Kim ${ }^{3}$ and \\ Ki Hyun Kim 1,* (iD) \\ 1 School of Pharmacy, Sungkyunkwan University, Suwon 16419, Korea; baekd5nie@gmail.com (J.B.); \\ charmelon8@gmail.com (T.K.L.) \\ 2 College of Pharmacy, Kangwon National University, Chuncheon 24341, Korea; \\ thdwohud@naver.com (J.-H.S.); hjko@kangwon.ac.kr (H.-J.K.) \\ 3 Sungkyun Biotech Co. Ltd., Suwon 16419, Korea; eychoi8812@sungkyunbiotech.co.kr (E.C.); \\ seonhee31@gmail.com (S.-H.K.) \\ 4 Department of Integrative Plant Science, Chung-Ang University, Anseong 17546, Korea; slee@cau.ac.kr \\ 5 Korea Research Institute of Chemical Technology (KRICT), Daejeon 34114, Korea; suchoi@krict.re.kr \\ 6 Dankook University Hospital Research Institute of Clinical Medicine, Cheonan 31116, Korea; \\ seonglee@empas.com \\ $7 \quad$ Research \& Development Center, Natural Way Co., Ltd., Pocheon 11160, Korea; nmrnmr@hanmail.net \\ * Correspondence: khkim83@skku.edu; Tel.: +82-31-290-7700
}

Received: 9 July 2018; Accepted: 30 July 2018; Published: 1 August 2018

\begin{abstract}
Lespedeza cuneata (Fabaceae), known as Chinese bushclover, has been used in traditional medicines for the treatment of diseases including diabetes, hematuria, and insomnia. As part of a continuing search for bioactive constituents from Korean medicinal plant sources, phytochemical analysis of the aerial portion of L. cuneata led to the isolation of two new lignan glycosides $(\mathbf{1 , 2})$ along with three known lignan glycosides (3-7) and nine known flavonoid glycosides (8-14). Numerous analysis techniques, including 1D and 2D NMR spectroscopy, CD spectroscopy, HR-MS, and chemical reactions, were utilized for structural elucidation of the new compounds $(\mathbf{1}, \mathbf{2})$. The isolated compounds were evaluated for their applicability in medicinal use using cell-based assays. Compounds $\mathbf{1}$ and 4-6 exhibited weak cytotoxicity against four human breast cancer cell lines (Bt549, MCF7, MDA-MB-231, and HCC70) ( $\left.\mathrm{IC}_{50}<30.0 \mu \mathrm{M}\right)$. However, none of the isolated compounds showed significant antiviral activity against PR8, HRV1B, or CVB3. In addition, compound $\mathbf{1 0}$ produced fewer lipid droplets in Oil Red O staining of mouse mesenchymal stem cells compared to the untreated negative control without altering the amount of alkaline phosphatase staining.
\end{abstract}

Keywords: Lespedeza cuneata; lignan glycoside; flavonoid glycoside; cytotoxicity; adipocyte and osteoblast differentiation

\section{Introduction}

Lespedeza cuneata (Dum. Cours.) G. Don. (Fabaceae), known as Chinese bushclover, is a warm-season, perennial legume that is widely distributed in Korea, China, and India [1]. This plant has been used in folk medicine for the treatment of diseases, including diabetes, hematuria, and insomnia, as well as for the protection of the kidneys, liver, and lungs [2,3]. Previous pharmacological studies of this medicinal plant have revealed that extracts of L. cuneata exhibit inhibition of inflammatory mediators in Lipopolysaccharide (LPS)-activated RAW264.7 cells and paw edema in carrageenan-stimulated 
rats [4], as well as hepatoprotective and antidiabetic effects [1,2,5,6]. A recent study of L. cuneata extract reported its in vitro cytotoxic effects against several cancer cell lines including HeLa, Hep3B, A549, and Sarcoma180 [7]. In terms of phytochemical components, it is a rich source of various compounds such as steroids, flavonoids, phenolics [3,6,8], phenylpropanoids [2,9], lignans [5,9], and phenyldilactones [10]. Among the constituents, lignans, and flavonoids are the main components of L. cuneata, and the lignans were found to have hepatoprotective [5] and anti-ulcerative colitis activities [9], and the flavonoids were reported to show hepatoprotective [6] and NO-inhibitory effects [11].

As part of a continuing search for bioactive constituents from Korean medicinal plant sources [12-14], the methanol $(\mathrm{MeOH})$ extract of the aerial portion of L. cuneata was found to exhibit cytotoxic effects on human ovarian carcinoma cells [15]. In our recent study, bioassay-guided fractionation and repeated chromatography of the $\mathrm{MeOH}$ extract of L. cuneata resulted in isolation of (-)-9'-O-( $\alpha$-L-rhamnopyranosyl)lyoniresinol, which suppresses the proliferation of A2780 human ovarian carcinoma cells through induction of apoptosis [15]. In the current study investigating bioactive compounds from the aerial portion of L. cuneata, further phytochemical analysis was carried out, which led to the isolation of two new lignan glycosides $(\mathbf{1}, \mathbf{2})$ along with three known lignan glycosides (3-7) and nine known flavonoid glycosides (8-14). Numerous analysis techniques, including 1D and 2D NMR spectroscopy, CD spectroscopy, HR-MS, and chemical reactions, were utilized for structural elucidation of the new compounds $(\mathbf{1}, \mathbf{2})$. Subsequently, we investigated the possible therapeutic effects of the isolated compounds using various cell-based assays. In this paper, we describe the isolation and structural characterization of compounds 1-14 (Figure 1), as well as the evaluation of their applicability to medicinal use including their cytotoxicity, antiviral activity, and their effects on the regulation of adipocyte and osteoblast differentiation.

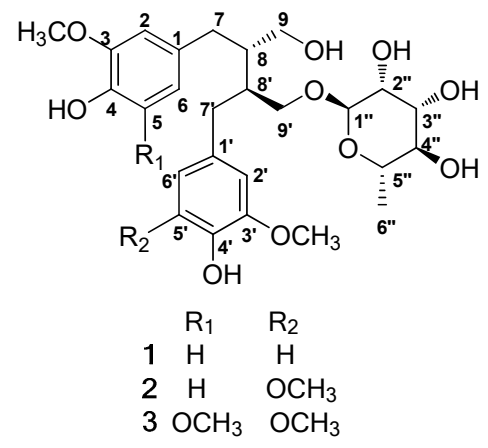<smiles>[R]c1c(O)c([R])c2oc(-c3ccc(O)cc3)c([R])c(=O)c2c1O</smiles><smiles>COc1cc([C@H]2c3cc(O)c(OC)cc3C[C@H]2CO[C@@H]2O[C@H](CO)[C@@H](O)[C@H](O)[C@H]2O)ccc1O</smiles>

4<smiles>COc1cc(C[C@@H]2CO[C@@H](c3ccc(O)c(OC)c3)[C@H]2COC2O[C@H](CO)[C@@H](O)[C@H](O)[C@H]2O)ccc1O</smiles>

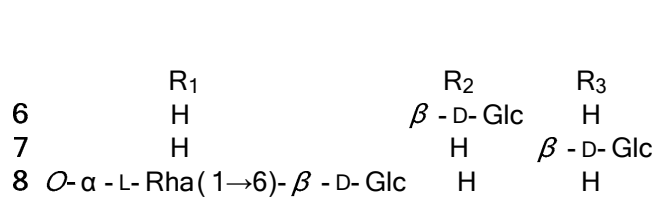<smiles>[R2]c1cc(-c2oc3cc(O)cc(O)c3c(=O)c2[R])cc(O)c1O</smiles>

$\mathrm{R}_{1}$

$O-\beta$ - D - Glc

$0-\alpha-\mathrm{L}-\mathrm{Rh} a$

$0-\alpha-\mathrm{L}-\mathrm{Ara}(\mathrm{f})$

$O-\alpha-$ L-Rha $(1 \rightarrow 6)-\beta$ - D- Glc

0 - $\alpha$ - L-Rha

$O-\alpha-\mathrm{L}-\mathrm{Ara}(\mathrm{f})$

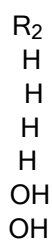

Figure 1. Chemical structures of compounds 1-14. Glc, glucopyranosyl; Rha, rhamnopyranosyl; Ara(f), arabinofuranosyl. 


\section{Results and Discussion}

\subsection{Isolation of the Compounds}

The dried aerial portion of L. cuneata was extracted with $80 \% \mathrm{MeOH}$ to produce the methanolic extract, which was sequentially solvent-partitioned with hexane, $\mathrm{CH}_{2} \mathrm{Cl}_{2}, \mathrm{EtOAc}$, and $n$ - $\mathrm{BuOH}$ to obtain each solvent fraction. Phytochemical analysis of the EtOAc fraction using repeated column chromatography and high performance liquid chromatography (HPLC) purification led to the isolation of two new lignan glycosides $(\mathbf{1}, \mathbf{2})$ along with three known lignan glycosides $(\mathbf{3}-\mathbf{7})$ and nine known flavonoid glycosides (8-14) (Figure 1).

\subsection{Structure Elucidation of the Compounds}

Compound (1) was isolated as a colorless gum with an optical rotation of $\left([\alpha]_{\mathrm{D}}^{25}+24.0(c 0.05\right.$, $\mathrm{MeOH})$. The molecular formula was determined to be $\mathrm{C}_{26} \mathrm{H}_{36} \mathrm{O}_{10}$ from the molecular ion peak $[\mathrm{M}+\mathrm{H}]^{+}$ at $m / z 509.2384$ (calculated for $\mathrm{C}_{26} \mathrm{H}_{37} \mathrm{O}_{10}$ 509.2387) in positive mode High-resolution electrospray ionisation mass spectrometry (HRESIMS) and the NMR spectroscopic data (Table 1). The infrared (IR) spectrum exhibited absorptions of hydroxy groups $\left(3351 \mathrm{~cm}^{-1}\right)$ and phenyl rings $\left(1521\right.$ and $\left.1455 \mathrm{~cm}^{-1}\right)$. The ${ }^{1} \mathrm{H}$ NMR spectrum (Table 1) showed signals from two sets of aromatic protons, one at $\delta_{\mathrm{H}} 6.67$ $(1 \mathrm{H}, \mathrm{d}, J=8.0 \mathrm{~Hz}, \mathrm{H}-5), 6.56(1 \mathrm{H}, \mathrm{d}, J=2.0 \mathrm{~Hz}, \mathrm{H}-2)$, and $6.53(1 \mathrm{H}, \mathrm{dd}, J=8.0,2.0 \mathrm{~Hz}, \mathrm{H}-6)$ and another at $\delta_{\mathrm{H}} 6.66\left(1 \mathrm{H}, \mathrm{d}, J=8.0 \mathrm{~Hz}, \mathrm{H}-5^{\prime}\right), 6.54\left(1 \mathrm{H}, \mathrm{d}, J=2.0 \mathrm{~Hz}, \mathrm{H}-2^{\prime}\right)$, and $6.53(1 \mathrm{H}, \mathrm{dd}, J=8.0$, $\left.2.0 \mathrm{~Hz}, \mathrm{H}-6^{\prime}\right)$, as well as two methoxy groups at $\delta_{\mathrm{H}} 3.74(3 \mathrm{H}, \mathrm{s})$ and $3.73(3 \mathrm{H}, \mathrm{s})$. The characteristic NMR data of 1, combined with heteronuclear single quantum correlation (HSQC) data, also showed signals for four methylenes at $\delta_{\mathrm{H}} 3.77\left(1 \mathrm{H}, \mathrm{dd}, J=10.0,6.0 \mathrm{~Hz}, \mathrm{H}-9{ }^{\prime} \mathrm{a}\right)$ and $3.33\left(1 \mathrm{H}, \mathrm{m}, \mathrm{H}-9^{\prime} \mathrm{b}\right) / \delta_{\mathrm{C}}$ $69.7\left(\mathrm{C}-9^{\prime}\right), \delta_{\mathrm{H}} 3.69(1 \mathrm{H}, \mathrm{m}, \mathrm{H}-9 \mathrm{a})$, and $3.48(1 \mathrm{H}, \mathrm{dd}, J=11.0,7.0 \mathrm{~Hz}, \mathrm{H}-9 \mathrm{~b}) / \delta_{\mathrm{C}} 62.6(\mathrm{C}-9), \delta_{\mathrm{H}} 2.67$ $(1 \mathrm{H}, \mathrm{dd}, J=14.0,7.0 \mathrm{~Hz}, \mathrm{H}-7 \mathrm{a})$ and $2.56(1 \mathrm{H}, \mathrm{dd}, J=14.0,8.5 \mathrm{~Hz}, \mathrm{H}-7 \mathrm{~b}) / \delta_{\mathrm{C}} 35.6(\mathrm{C}-7)$, and $\delta_{\mathrm{H}} 2.60$ $\left(2 \mathrm{H}, \mathrm{m}, \mathrm{H}-7^{\prime}\right) / \delta_{\mathrm{C}} 35.8\left(\mathrm{C}-7^{\prime}\right)$, and two methines at $\delta_{\mathrm{H}} 2.07\left(1 \mathrm{H}, \mathrm{m}, \mathrm{H}-8^{\prime}\right) / \delta_{\mathrm{C}} 40.7\left(\mathrm{C}-8^{\prime}\right)$ and $1.94(1 \mathrm{H}$, $\mathrm{m}, \mathrm{H}-8) / \delta_{\mathrm{C}} 44.1$ (C-8), which are indicative of a secoisolariciresinol-type lignan [16,17]. In addition, characteristic rhamnose NMR signals were observed at $\delta_{\mathrm{H}} 4.63\left(1 \mathrm{H}, \mathrm{d}, J=1.5 \mathrm{~Hz}, \mathrm{H}-1^{\prime \prime}\right)$ and $1.25(3 \mathrm{H}$, $\left.\mathrm{d}, J=6.0 \mathrm{~Hz}, \mathrm{H}-6^{\prime \prime}\right), \delta_{\mathrm{C}} 102.0,73.7,72.4,72.2,69.9$, and 17.8 [18]. These data suggest that compound $\mathbf{1}$ is a secoisolariciresinol-type lignan glycoside, and the ${ }^{1} \mathrm{H}$ and ${ }^{13} \mathrm{C}$ NMR spectra of $\mathbf{1}$ were highly similar to those of $(-)$-secoisolariciresinol-O- $\alpha$-L-rhamnopyranoside [19]. The planar gross structure of 1 was established based on the ${ }^{1} \mathrm{H}-{ }^{1} \mathrm{H}$ correlation spectroscopy (COSY) and Heteronuclear multiple bond correlation (HMBC) spectral data (Figure 2). However, the absolute stereochemistry of 1 was not identical to (-)-secoisolariciresinol-O- $\alpha$-L-rhamnopyranoside because compound 1 showed a positive optical rotation $\left([\alpha]_{\mathrm{D}}^{25}+24.0, c 0.05, \mathrm{MeOH}\right)$ similar to chaenomiside $\mathrm{F}$ (compound 3$)\left([\alpha]_{\mathrm{D}}^{25}\right.$ $+30.0, c 0.1, \mathrm{MeOH}$ ) [20] and (-)-secoisolariciresinol-O- $\alpha$-L-rhamnopyranoside showed a negative rotation $\left([\alpha]_{\mathrm{D}}^{20}-49.5, c 0.30\right.$, acetone) [19]. Enzymatic hydrolysis was carried out to further confirm the absolute configuration of compound 1, which yielded an aglycone and a rhamnose. The aglycone was determined to be (+)-secoisolariciresinol (1a) through LC/MS analysis with an $\mathrm{m} / z$ signal of 361.2 $[\mathrm{M}-\mathrm{H}]^{-}$and a positive optical rotation $\left([\alpha]_{\mathrm{D}}^{25}+30.0, c 0.02\right.$, acetone $)$ [16]. The CD spectrum of 1a showed positive Cotton effects at 209, 223, and $288 \mathrm{~nm}$, and negative effects at 216 and $230 \mathrm{~nm}$, which is the first report of an experimental CD spectrum of (+)-secoisolariciresinol. The coupling constant $(J=1.5 \mathrm{~Hz})$ of the anomeric proton of the rhamnose revealed the $\alpha$-configuration of the anomeric proton [21]. The identity of L-rhamnose was established through LC/MS analysis of the rhamnose obtained from the enzymatic hydrolysis [22,23]. Thus, the structure of compound 1 was determined to be (+)-secoisolariciresinol-O- $\alpha$-L-rhamnopyranoside. 


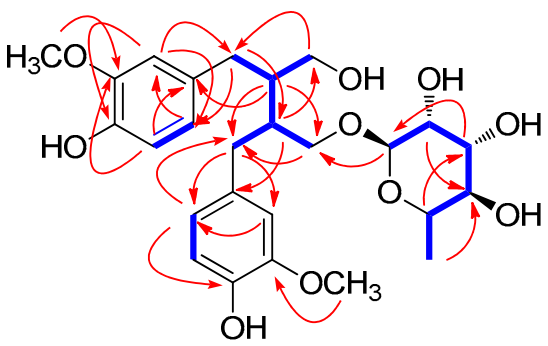

1

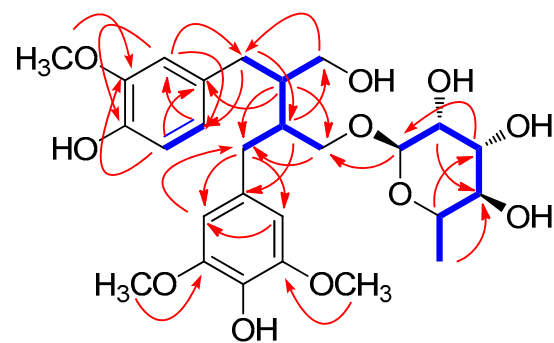

2

Figure 2. ${ }^{1} \mathrm{H}-{ }^{1} \mathrm{H} \operatorname{COSY}(-)$ and key $\operatorname{HMBC}(\frown)$ correlations for $\mathbf{1}$ and 2.

Table 1. ${ }^{1} \mathrm{H}$ and ${ }^{13} \mathrm{C}$ NMR data of 1 and 2 in $\mathrm{CD}_{3} \mathrm{OD}\left(\delta\right.$ in ppm, $800 \mathrm{MHz}$ for ${ }^{1} \mathrm{H}$ and $200 \mathrm{MHz}$ for $\left.{ }^{13} \mathrm{C}\right){ }^{\mathrm{a}}$.

\begin{tabular}{|c|c|c|c|c|c|c|}
\hline \multirow{2}{*}{ Position } & \multicolumn{3}{|c|}{1} & \multicolumn{3}{|c|}{2} \\
\hline & $\delta_{H}$ & $\delta_{C}$ & & $\delta_{H}$ & $\delta_{C}$ & \\
\hline 1 & & 133.6 & $\mathrm{~s}$ & & 132.2 & $\mathrm{~s}$ \\
\hline 2 & $6.56 \mathrm{~d}(2.0)$ & 113.0 & $\mathrm{~d}$ & $6.54 \mathrm{~d}(2.0)$ & 111.9 & $\mathrm{~d}$ \\
\hline 3 & $6.67^{\alpha} \mathrm{d}(8.0)$ & 115.5 & $\mathrm{~d}$ & $6.65 \mathrm{~d}(8.0)$ & 114.2 & $\mathrm{~d}$ \\
\hline 4 & & 145.4 & $\mathrm{~s}$ & & 144.5 & $\mathrm{~s}$ \\
\hline 5 & & 148.9 & $\mathrm{~s}$ & & 147.5 & $\mathrm{~s}$ \\
\hline 6 & $6.53 \mathrm{dd}(8.0,2.0)$ & 122.6 & $\mathrm{~d}$ & $6.52 \mathrm{dd}(8.0,2.0)$ & 121.3 & d \\
\hline 7 & $\begin{array}{l}2.67 \mathrm{dd}(14.0,7.0) \\
2.56 \mathrm{dd}(14.0,8.5)\end{array}$ & 35.6 & $\mathrm{t}$ & $\begin{array}{l}2.69 \mathrm{dd}(14.0,6.5) \\
2.53 \mathrm{dd}(14.0,9.0)\end{array}$ & 34.5 & $\mathrm{t}$ \\
\hline 8 & $1.94 \mathrm{~m}$ & 44.1 & $\mathrm{~d}$ & $1.92 \mathrm{~m}$ & 42.5 & d \\
\hline 9 & $\begin{array}{c}3.69 \mathrm{~m} ; \\
3.48 \mathrm{dd}(11.0,7.0)\end{array}$ & 62.6 & $\mathrm{t}$ & $\begin{array}{c}3.71 \mathrm{~m} ; \\
3.48 \mathrm{dd}(11.0,7.0)\end{array}$ & 61.2 & $\mathrm{t}$ \\
\hline $1^{\prime}$ & & 133.6 & $\mathrm{~s}$ & & 131.4 & $\mathrm{~s}$ \\
\hline $2^{\prime}$ & $6.54 \mathrm{~d}(2.0)$ & 113.0 & $\mathrm{~d}$ & $6.28 \mathrm{~s}$ & 105.3 & $\mathrm{~d}$ \\
\hline $3^{\prime}$ & & 148.8 & $\mathrm{~s}$ & & 147.6 & $\mathrm{~s}$ \\
\hline $4^{\prime}$ & & 145.4 & $\mathrm{~s}$ & & 133.4 & $\mathrm{~s}$ \\
\hline $5^{\prime}$ & $6.66^{\alpha} \mathrm{d}(8.0)$ & 115.5 & $\mathrm{~d}$ & & 147.6 & $\mathrm{~s}$ \\
\hline $6^{\prime}$ & $6.53 \mathrm{dd}(8.0,2.0)$ & 122.6 & $\mathrm{~d}$ & $6.28 \mathrm{~s}$ & 105.3 & d \\
\hline $7^{\prime}$ & $2.60 \mathrm{~m}$ & 35.8 & $\mathrm{t}$ & $2.60 \mathrm{~m}$ & 35.2 & $\mathrm{t}$ \\
\hline $8^{\prime}$ & $2.07 \mathrm{~m}$ & 40.7 & $\mathrm{~d}$ & $2.08 \mathrm{~m}$ & 39.3 & $\mathrm{~d}$ \\
\hline $9^{\prime}$ & $\begin{array}{c}3.77 \mathrm{dd}(10.0,6.0) ; \\
3.33 \mathrm{~m}\end{array}$ & 69.7 & $\mathrm{t}$ & $\begin{array}{c}3.79 \mathrm{dd}(10.0,6.0) ; \\
3.35 \mathrm{~m}\end{array}$ & 67.9 & $\mathrm{t}$ \\
\hline $1^{\prime \prime}$ & $4.63 \mathrm{~d}(1.5)$ & 102.0 & $\mathrm{~d}$ & $4.64 \mathrm{~d}(1.5)$ & 100.7 & d \\
\hline $2^{\prime \prime}$ & $3.82 \mathrm{dd}(3.5,1.5)$ & 72.2 & $\mathrm{~d}$ & $3.81 \mathrm{dd}(3.5,1.5)$ & 71.0 & $\mathrm{~d}$ \\
\hline $3^{\prime \prime}$ & $3.68 \mathrm{dd}(9.5,3.5)$ & 72.4 & $\mathrm{~d}$ & $3.68 \mathrm{dd}(9.5,3.5)$ & 71.1 & d \\
\hline $4^{\prime \prime}$ & $3.38 \mathrm{t}(9.5)$ & 73.7 & $\mathrm{~d}$ & $3.38 \mathrm{t}(9.5)$ & 72.5 & $\mathrm{~d}$ \\
\hline $5^{\prime \prime}$ & $3.62 \mathrm{dq}(9.5,6.0)$ & 69.9 & $\mathrm{~d}$ & $3.62 \mathrm{dq}(9.5,6.0)$ & 68.7 & d \\
\hline $6^{\prime \prime}$ & $1.25 \mathrm{~d}(6.0)$ & 17.8 & $\mathrm{q}$ & $1.25 \mathrm{~d}(6.0)$ & 16.5 & $\mathrm{q}$ \\
\hline $3-\mathrm{OCH}_{3}$ & $3.73^{\beta} \mathrm{s}$ & 55.8 & $\mathrm{q}$ & $3.72 \mathrm{~s}$ & 54.7 & $\mathrm{q}$ \\
\hline $3^{\prime}-\mathrm{OCH}_{3}$ & $3.74^{\beta} \mathrm{s}$ & 55.8 & $\mathrm{q}$ & $3.74 \mathrm{~s}$ & 55.1 & $\mathrm{q}$ \\
\hline $5^{\prime}-\mathrm{OCH}_{3}$ & & & & $3.74 \mathrm{~s}$ & 55.1 & $\mathrm{q}$ \\
\hline
\end{tabular}

a $J$ values are in parentheses and reported in $\mathrm{Hz} ;{ }^{13} \mathrm{C}$ NMR assignments based on ${ }^{1} \mathrm{H}_{-}{ }^{1} \mathrm{H}$ COSY, $\mathrm{HSQC}$, and $\mathrm{HMBC}$ experiments; ${ }^{\alpha, \beta}$ Exchangeable peaks.

Compound 2 was obtained as a colorless gum with a positive optical rotation value of $[\alpha]_{D}^{25}+27.5$ (c $0.04, \mathrm{MeOH}$ ). The molecular formula of 2 was determined to be $\mathrm{C}_{27} \mathrm{H}_{38} \mathrm{O}_{11}$ from the molecular ion peak at $m / z 537.2343[\mathrm{M}-\mathrm{H}]^{-}$(calculated for $\mathrm{C}_{27} \mathrm{H}_{37} \mathrm{O}_{11}$ 537.2336) in the negative mode HRESIMS and the NMR spectroscopic data (Table 1). The ultraviolet (UV) and IR spectra of 2 were almost identical to those of $\mathbf{1}$. The ${ }^{1} \mathrm{H}$ and ${ }^{13} \mathrm{C}$ NMR spectra (Table 1 ) were also quite similar to those of $\mathbf{1}$, with a noticeable difference being that the proton signals for a 1,3,4-trisubstituted aromatic ring in 1 were absent and the proton signals for a typical 1,3,4,5-tetrasubstituted aromatic ring $\left(\delta_{\mathrm{H}} 6.28(2 \mathrm{H}, \mathrm{s})\right)$ 
and an overlapped signal for two methoxyl groups $\left(\delta_{\mathrm{H}} 3.74(6 \mathrm{H}, \mathrm{s})\right)$ was present in 2 . In light of these data, compound $\mathbf{2}$ was also deduced to be one of the secoisolariciresinol-type lignans like compound $\mathbf{1}$, and the differences in the structure of $\mathbf{2}$ compared to compound $\mathbf{1}$ were confirmed through analysis of the ${ }^{1} \mathrm{H}-{ }^{1} \mathrm{H}$ COSY and HMBC data (Figure 2). Specifically, an HMBC correlation from the methoxyl group $\left(\delta_{\mathrm{H}} 3.74\right)$ to $C-3^{\prime} / \mathrm{C}-5^{\prime}\left(\delta_{\mathrm{C}} 147.6\right)$ was observed, which led to the assignment of the methoxyl group at C-3'/C-5'. The similarity between the characteristic CD curves of 1 (positive at 206, 229, and $285 \mathrm{~nm}$ and negative at $217 \mathrm{~nm}$ ) and 2 (positive at 205, 233, and $283 \mathrm{~nm}$ and negative at $221 \mathrm{~nm}$ ) revealed that the absolute configuration of $\mathbf{2}$ was identical to compound $\mathbf{1}$ as the $8 \mathrm{~S}$ and 8'S form, which was also supported by the positive optical rotation value $\left([\alpha]_{D}^{25}+27.5, c 0.04, \mathrm{MeOH}\right)$ of 2 like that of 1. Enzymatic hydrolysis was conducted to further confirm the absolute configuration of 2 , which yielded an aglycone (2a) and a rhamnose. As expected, the aglycone (2a) was determined to be (+)-seco-5'-methoxy-isolariciresinol using LC/MS analysis with an $m / z$ signal of $393.2[\mathrm{M}+\mathrm{H}]^{+}$and a positive optical rotation value of $2 \mathbf{a}\left([\alpha]_{D}^{25}+25.5, c 0.02\right.$, acetone $)$ [16]. The characteristic small coupling constant $(J=1.5 \mathrm{~Hz})$ of the anomeric proton of the rhamnose at $\delta_{\mathrm{H}} 4.64$ indicated the $\alpha$-configuration of the rhamnose [21], and L-rhamnose was confirmed using LC/MS analysis of the rhamnose obtained from the enzymatic hydrolysis of $\mathbf{2}$ [22,23]. Accordingly, the structure of compound 2 was determined to be (+)-seco-5'-methoxy-isolariciresinol-9'-O- $\alpha$-L-rhamnopyranoside.

The known compounds were identified as chaenomiside F (3) [16,20], (+)-isolariciresinol 9-O- $\beta$-D-glucoside (4) [5], lariciresinol 9-O- $\beta$-D-glucopyranoside (5) [24], isovitexin (6) [25], vitexin (7) [26], nicotiflorin (8) [27], isoquercetin (9) [28], quercimelin (10) [29], avicularin (11) [30], rutin (12) [28], myricitrin (13) [31], and betmidin (14) [32,33], through comparison of their spectroscopic data, including ${ }^{1} \mathrm{H}$ and ${ }^{13} \mathrm{C} \mathrm{NMR}$, and physical data with previously reported values, as well as through LC/MS analysis.

\subsection{Cytotoxic Activity of Isolated Compounds against Human Tumor Cell Lines}

Based on the cytotoxic activity of the $\mathrm{MeOH}$ extract of L. cuneata in our recent study [15], the cytotoxic activities of the isolated compounds (1-14) were evaluated by determining their inhibitory effects on human tumor cell growth in human breast cancer cells (Bt549, MCF7, MDA-MB-231 and HCC70), using a sulforhodamine B (SRB) bioassay [12,34]. The results (Table S1) demonstrated that compound 1 showed cytotoxicity against Bt549, MDA-MB-231, and HCC70 cell lines with $\mathrm{IC}_{50}$ values ranging from $24.38-26.16 \mu \mathrm{M}$. Compounds 4 and 5 exhibited cytotoxicity against MCF7 (IC $50: 28.08 \mu \mathrm{M})$ and HCC70 ( $\left.\mathrm{IC}_{50}: 24.81 \mu \mathrm{M}\right)$ cell lines, respectively, and compound 6 showed cytotoxic activity against MCF7, MDA-MB-231, and HCC70 cell lines with $\mathrm{IC}_{50}$ values ranging from 27.57-29.18 $\mu \mathrm{M}$ (Table S1). However, other compounds were inactive $\left(\mathrm{IC}_{50}>30.0 \mu \mathrm{M}\right)$. Although recent studies of L. cuneata extract have reported that the extract showed cytotoxic effects against various cancer cell lines $[7,15]$, the isolated compounds (1-14) did not appear to be responsible for the cytotoxicity.

\subsection{Antiviral Activity of the Isolated Compounds against PR8, HRV1B, and CVB3 Infection}

Recently, many studies exploring antiviral natural products and organic synthetic compounds have reported that a variety of flavonoids exhibit potent antiviral activity by inhibiting the early stages of viral infection, viral protein expression, and neuraminidase activity [35-37]. Therefore, we assessed the isolated compounds (1-14) for their antiviral activity against PR8, HRV1B, and CVB3 infection in A549, Vero, and HeLa cells, respectively. Less than $10 \%$ of the cells survived in the positive-control group (cells with virus only) after 48 hours of infection. In addition, cells treated with compounds 1-14 $(10 \mu \mathrm{M})$ also had less than 10\% survival. Because we could not identify any significant differences between the control and test groups, these results suggest that the compounds do not show significant antiviral activity against PR8, HRV1B, or CVB3. 


\subsection{Regulatory Effects of Compound $\mathbf{1 0}$ on Differentiation into Adipocytes and Osteoblasts}

Mesenchymal stem cells (MSCs) in the bone marrow are pluripotent cells, which differentiate into osteocytes as well as adipocytes. Since microenvironmental changes such as hormones, immune responses, and metabolism cause alterations in the regulation of MSC differentiation, where alterations in the expression of the related genes might disturb the balance between osteoprogenitor and adipocyte progenitor cells in osteoporosis patients [38], natural products that are able to suppress MSC differentiation toward adipocytes and/or promote osteogenic differentiation of MSC would be promising in the management of postmenopausal osteoporosis. The biological activity of compound 10 was additionally tested regarding its effects on the differentiation of mouse MSCs into adipocytes or osteoblasts, since large amounts of compound $\mathbf{1 0}$ was isolated among the isolated compounds. Compound 10 was added to the MSC culture media during adipocyte differentiation. Compound 10 slightly reduced the formation of lipid droplets and resulted in somewhat fewer Oil Red $\mathrm{O}$ (ORO)-stained cells compared to the normally differentiated adipocytes (Figure 3A). However, ALP staining and ALP activity in the compound 10-treated cells did not increase during the MSC differentiation into osteoblasts, in contrast to the positive control group treated with oryzativol A (Figure 3B). These results demonstrate that compound $\mathbf{1 0}$ marginally suppressed adipogenesis of MSCs but did not influence osteogenesis.

$\mathbf{A}$
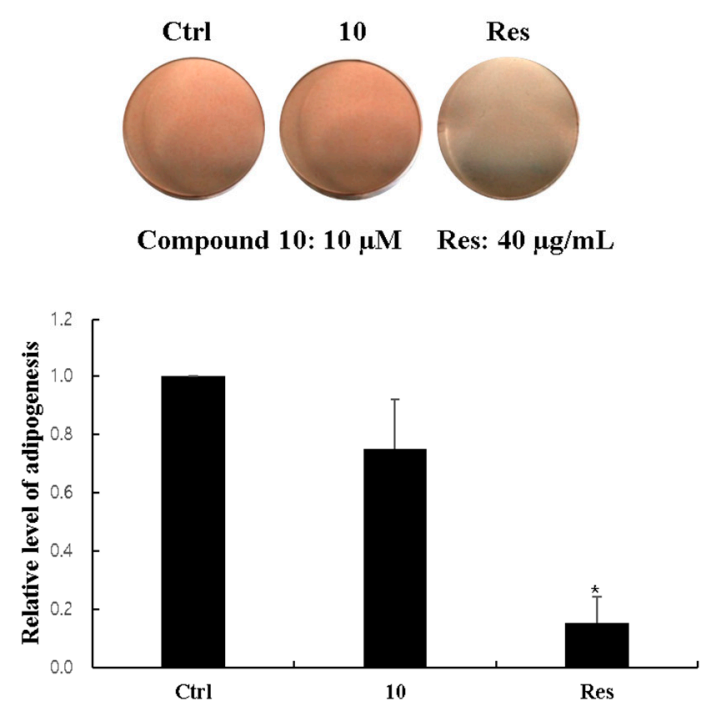

B
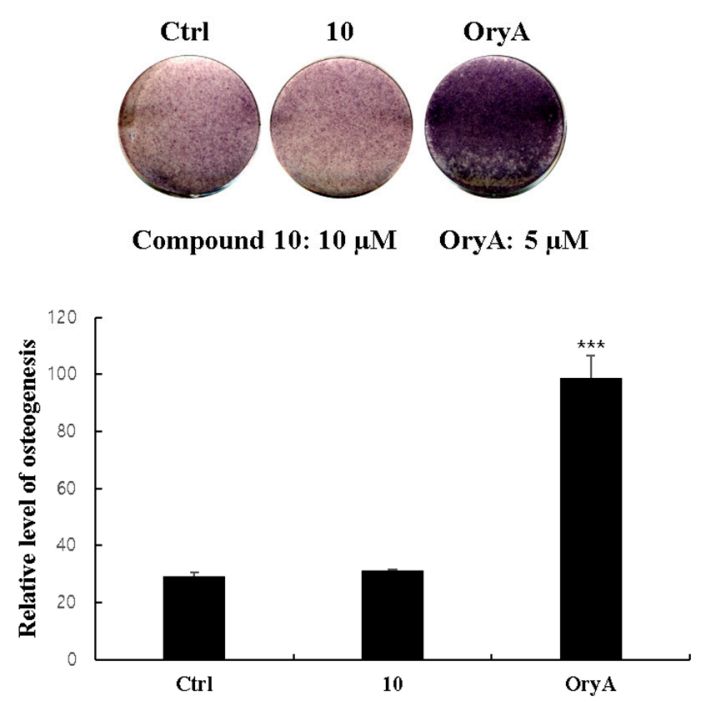

Figure 3. Reciprocal effects of compound $\mathbf{1 0}$ on the differentiation of MSCs into adipocytes or osteoblasts. Mouse mesenchymal stem cells (C3H10T1/2) were treated with $10 \mu \mathrm{M}$ compound 10. After adipogenic differentiation, the cells were stained with Oil Red O (ORO), and the number of stained lipid droplets was quantitatively evaluated (A). After osteoblast differentiation, the cells were stained for ALP levels, and the ALP activity was measured (B). Ctrl represents untreated negative control. For the positive controls, 40 micrograms of resveratrol (Res) was used for adipogenesis and $5 \mu \mathrm{M}$ of oryzativol A (OryA) was added for osteogenesis. ${ }^{*}$ denotes $0.01 \leq p \leq 0.05$ and ${ }^{* * *}$ denotes $p<0.001$.

\section{Materials and Methods}

\subsection{Plant Material}

The aerial portions of L. cuneata were collected from Mt. Bangtae, Inje, Kangwon Province, Republic of Korea, in October 2016. The plant materials were identified by one of the authors, Prof. S. Lee. A voucher specimen (YKM-2016) was deposited at the herbarium of the School of Pharmacy, Sungkyunkwan University, Suwon, Republic of Korea. 


\subsection{Extraction and Isolation}

The dried aerial portions of L. cuneata $(4.2 \mathrm{~kg}$ ) were extracted three times with $4.2 \mathrm{~L}$ of $80 \% \mathrm{MeOH}$ for three days at room temperature and filtered. The resultant filtrate was evaporated under reduced pressure using a rotavap to obtain the $\mathrm{MeOH}$ extract $(401.8 \mathrm{~g})$, which was suspended in distilled $\mathrm{H}_{2} \mathrm{O}$ (2 L) and successively solvent-partitioned with hexane, $\mathrm{CH}_{2} \mathrm{Cl}_{2}$, EtOAc, and $n$ - $\mathrm{BuOH}(2.0 \mathrm{~L} \times 3$ for each) to yield the hexane- $(20.6 \mathrm{~g}), \mathrm{CH}_{2} \mathrm{Cl}_{2}-(0.7 \mathrm{~g})$, EtOAc- $(12.7 \mathrm{~g})$, and $n$-BuOH-soluble $(69.3 \mathrm{~g})$ fractions The EtOAc-soluble fraction (12.7 g) was subjected to Diaion HP-20 column chromatography with a gradient solvent system of $\mathrm{MeOH}-\mathrm{H}_{2} \mathrm{O}(0-100 \% \mathrm{MeOH})$ to afford six fractions (A-F). Fraction D (5.4 g) was separated using RP-C18 column chromatography with a gradient solvent system of $\mathrm{MeOH}-\mathrm{H}_{2} \mathrm{O}$ $(30-100 \% \mathrm{MeOH})$ to yield six sub-fractions $\left(\mathrm{D}_{1}-\mathrm{D}_{6}\right)$. Sub-fraction $\mathrm{D}_{3}(2.8 \mathrm{~g})$ was fractionated using silica gel column chromatography with a gradient solvent system of $\mathrm{CH}_{2} \mathrm{Cl}_{2}-\mathrm{MeOH}-\mathrm{H}_{2} \mathrm{O}$ (15:1:0-9:3:0.5 $v / v / v)$ to produce $10 \mathrm{sub}$-fractions $\left(\mathrm{D}_{3}-1-\mathrm{D}_{3}-10\right)$. Sub-fraction $\mathrm{D}_{3}-7(1.1 \mathrm{~g})$ was separated using an RP-C18 column with $60 \% \mathrm{MeOH}$ to produce four sub-fractions $\left(\mathrm{D}_{3}-71-\mathrm{D}_{3}-74\right)$. Sub-fraction $\mathrm{D}_{3}-72$ (506.7 $\mathrm{mg}$ ) was subjected to silica gel column chromatography with a gradient solvent system of $\mathrm{CH}_{2} \mathrm{Cl}_{2}-\mathrm{MeOH}-\mathrm{H}_{2} \mathrm{O}(10: 1: 0-1: 1: 0.25, v / v / v)$ to give five sub-fractions $\left(\mathrm{D}_{3}-721-\mathrm{D}_{3}-725\right)$. Sub-fraction $\mathrm{D}_{3}-722$ (316.4 mg) was subjected to Sephadex LH-20 column chromatography with $100 \% \mathrm{MeOH}$ to produce 10 sub-fractions $\left(\mathrm{D}_{3}-722 \mathrm{~A}-\mathrm{D}_{3}-722 \mathrm{~J}\right)$. Sub-fraction $\mathrm{D}_{3}-722 \mathrm{C}(230.0 \mathrm{mg})$ was purified using semi-preparative HPLC with a Phenomenex Luna phenyl-hexyl column $(18 \% \mathrm{MeCN}$, flow rate: $2 \mathrm{~mL} / \mathrm{min})$ to yield compound $5\left(1.4 \mathrm{mg}, t_{R}=37.0 \mathrm{~min}\right)$. Sub-fraction $\mathrm{D}_{3}-73(158.8 \mathrm{mg})$ was subjected to Sephadex LH-20 column chromatography with $100 \% \mathrm{MeOH}$ to give 10 sub-fractions $\left(\mathrm{D}_{3}-73 \mathrm{~A}-\mathrm{D}_{3}-73 \mathrm{~J}\right)$. Compounds $2\left(0.7 \mathrm{mg}, t_{R}=49.5 \mathrm{~min}\right)$ and $3\left(1.8 \mathrm{mg}, t_{R}=41.5 \mathrm{~min}\right)$ were obtained from sub-fraction $\mathrm{D}_{3}$-73B (24.5 mg) using semi-preparative HPLC with a Phenomenex Luna phenyl-hexyl column (18\% $\mathrm{MeCN}$, flow rate: $2 \mathrm{~mL} / \mathrm{min})$. Compound $1\left(7.6 \mathrm{mg}, t_{R}=61.0 \mathrm{~min}\right)$ was isolated from sub-fraction $\mathrm{D}_{3}-73 \mathrm{C}$ (44.7 mg) using semi-preparative HPLC with a Phenomenex Luna phenyl-hexyl column (18\% $\mathrm{MeCN}$, flow rate: $2 \mathrm{~mL} / \mathrm{min})$. Compound $14\left(3.7 \mathrm{mg}, t_{R}=20.5 \mathrm{~min}\right)$ was obtained from sub-fraction $\mathrm{D}_{3}$-73I (8.2 mg) using semi-preparative HPLC with a Phenomenex Luna phenyl-hexyl column (21\% $\mathrm{MeCN}$, flow rate: $2 \mathrm{~mL} / \mathrm{min})$. Sub-fraction $\mathrm{D}_{3}-74(127.6 \mathrm{mg})$ was subjected to Sephadex LH-20 column chromatography with $100 \% \mathrm{MeOH}$ to give eight sub-fractions $\left(\mathrm{D}_{3}-741-\mathrm{D}_{3}-748\right)$. Compounds 9 (0.7 mg, $\left.t_{R}=30.5 \mathrm{~min}\right)$ and $10\left(32.8 \mathrm{mg}, t_{R}=48.0 \mathrm{~min}\right)$ were isolated from sub-fraction $\mathrm{D}_{3}-746(42.3 \mathrm{mg})$ using semi-preparative HPLC with a Phenomenex Luna phenyl-hexyl column (18\% MeCN, flow rate: $2 \mathrm{~mL} / \mathrm{min})$. Sub-fraction $\mathrm{D}_{3}-8(515.0 \mathrm{mg})$ was subjected to RP-C18 column chromatography using a gradient solvent system of $40-60 \% \mathrm{MeOH}$ to produce four sub-fractions $\left(\mathrm{D}_{3}-81-\mathrm{D}_{3}-84\right)$. Sub-fraction $\mathrm{D}_{3}-82$ (346.7 mg) was subjected to silica gel column chromatography with a gradient solvent system of $\mathrm{CH}_{2} \mathrm{Cl}_{2}-\mathrm{MeOH}(10: 1-1: 1, v / v)$ to give four sub-fractions $\left(\mathrm{D}_{3}-821-\mathrm{D}_{3}-824\right)$. Sub-fraction $\mathrm{D}_{3}-822$ (54.8 mg) was applied to Sephadex LH-20 column chromatography with $100 \% \mathrm{MeOH}$ to produce six sub-fractions $\left(\mathrm{D}_{3}-822 \mathrm{~A}-\mathrm{D}_{3}-822 \mathrm{~F}\right)$. Compound $4\left(3.5 \mathrm{mg}, t_{R}=39.0 \mathrm{~min}\right)$ was purified from sub-fraction $\mathrm{D}_{3}-822 \mathrm{~A}$ (16.3 mg) using semi-preparative HPLC with a Phenomenex Luna phenyl-hexyl column (15\% MeCN, flow rate: $2 \mathrm{~mL} / \mathrm{min})$. Sub-fraction $\mathrm{D}_{3}-824(78.1 \mathrm{mg})$ was separated using Sephadex LH-20 column chromatography with $100 \% \mathrm{MeOH}$ to yield five sub-fractions $\left(\mathrm{D}_{3}-824 \mathrm{~A}-\mathrm{D}_{3}-824 \mathrm{E}\right)$. Sub-fraction $\mathrm{D}_{3}-824 \mathrm{C}(22.4 \mathrm{mg})$ was separated using semi-preparative HPLC with a Phenomenex Luna phenyl-hexyl column $(16 \% \mathrm{MeCN}$, flow rate: $2 \mathrm{~mL} / \mathrm{min})$ to obtain compound $8\left(2.3 \mathrm{mg}, t_{R}=72.5 \mathrm{~min}\right)$. Sub-fraction $\mathrm{D}_{3}-824 \mathrm{D}$ (37.3 mg) was separated using semi-preparative HPLC with a Phenomenex Luna phenyl-hexyl column ( $14 \% \mathrm{MeCN}$, flow rate: $2 \mathrm{~mL} / \mathrm{min})$ to obtain compound $13\left(0.5 \mathrm{mg}, t_{R}=73.0 \mathrm{~min}\right)$, and compound 13's washing fraction $\mathrm{D}_{3}-824 \mathrm{DW}(20.5 \mathrm{mg})$ was collected. Compound 11 (1.0 mg, $t_{R}=49.5 \mathrm{~min}$ ) was purified using semi-preparative HPLC with a Phenomenex Luna phenyl-hexyl column (18\% MeCN, flow rate: $2 \mathrm{~mL} / \mathrm{min}$ ) from sub-fraction $\mathrm{D}_{3}-824 \mathrm{DW}$ (20.5 mg). Sub-fraction $\mathrm{D}_{3}-10$ (132.7 mg) was applied to Sephadex LH-20 column chromatography with $80 \% \mathrm{MeOH}$ to produce nine sub-fractions $\left(\mathrm{D}_{3}-101-\mathrm{D}_{3}-109\right)$. Sub-fraction $\mathrm{D}_{3}-108$ (50.3 $\left.\mathrm{mg}\right)$ was further separated using semi-preparative HPLC with a Phenomenex Luna phenyl-hexyl column (38\% MeOH, flow rate: $2 \mathrm{~mL} / \mathrm{min})$ to yield compound $12\left(2.1 \mathrm{mg}, t_{R}=72.0 \mathrm{~min}\right)$. Finally, compounds $6\left(0.6 \mathrm{mg}, t_{R}=37.0 \mathrm{~min}\right)$ 
and 7 (2.0 $\left.\mathrm{mg}, t_{R}=39.0 \mathrm{~min}\right)$ were isolated from sub-fraction $\mathrm{D}_{3}-109$ (17.2 $\left.\mathrm{mg}\right)$ using semi-preparative HPLC with a Phenomenex Luna phenyl-hexyl column (20\% MeCN, flow rate: $2 \mathrm{~mL} / \mathrm{min})$.

\subsection{1. (+)-Secoisolariciresinol-O- $\alpha$-L-rhamnopyranoside (1)}

Colorless gum; $[\alpha]_{\mathrm{D}}^{25}+24.0(c=0.05, \mathrm{MeOH})$; ESIMS (negative mode) $m / z: 507[\mathrm{M}-\mathrm{H}]^{-}$; HRESIMS (positive mode) $m / z: 509.2384[\mathrm{M}+\mathrm{H}]^{+}$, calculated for $\mathrm{C}_{26} \mathrm{H}_{37} \mathrm{O}_{10}, 509.2387 ; \mathrm{UV}(\mathrm{MeOH})$ $\lambda_{\max } \mathrm{nm}(\log \varepsilon): 205$ (2.29), 233 (3.43), 283 (0.76); IR (KBr) $v_{\max } \mathrm{cm}^{-1}:$ 3703, 3351, 2947, 2833, 2513, 2302, 2047, 1521, 1455; CD (MeOH) $\lambda_{\max } \mathrm{nm}(\Delta \varepsilon): 206(+19.2), 217(-11.5), 229(+10.3), 285(+2.8) ;{ }^{1} \mathrm{H}$ $\left(\mathrm{CD}_{3} \mathrm{OD}, 800 \mathrm{MHz}\right)$ and ${ }^{13} \mathrm{C}\left(\mathrm{CD}_{3} \mathrm{OD}, 200 \mathrm{MHz}\right) \mathrm{NMR}$ spectroscopic data, see Table 1.

3.2.2. (+)-Seco-5'-methoxy-isolariciresinol-9'-O- $\alpha$-L-rhamnopyranoside (2)

Colorless gum; $[\alpha]_{\mathrm{D}}^{25}+27.5(c=0.04, \mathrm{MeOH})$; ESIMS (negative mode) $m / z: 537[\mathrm{M}-\mathrm{H}]^{-}$; HRESIMS (negative mode) $m / z: 537.2343[\mathrm{M}-\mathrm{H}]^{-}$, calculated for $\mathrm{C}_{27} \mathrm{H}_{37} \mathrm{O}_{11}, 537.2341 ; \mathrm{UV}(\mathrm{MeOH})$ $\lambda_{\max }$ nm (log $\varepsilon$ ): 205 (2.29), 233 (3.43), 283 (0.76); IR (KBr) $v_{\max } \mathrm{cm}^{-1}:$ 3705, 3340, 2945, 2831, 2512, 2302, 2045, 1516, 1453; CD (MeOH) $\lambda_{\max } \mathrm{nm}(\Delta \varepsilon)$ : 205 (+11.5), $221(-23.4), 233(+13.8), 283(+3.1) ;{ }^{1} \mathrm{H}$ $\left(\mathrm{CD}_{3} \mathrm{OD}, 800 \mathrm{MHz}\right)$ and ${ }^{13} \mathrm{C}\left(\mathrm{CD}_{3} \mathrm{OD}, 200 \mathrm{MHz}\right) \mathrm{NMR}$ spectroscopic data, see Table 1.

\subsection{Enzymatic Hydrolysis of Compounds $\mathbf{1 , 2}$}

A solution of each compound $(1.0 \mathrm{mg})$ in $\mathrm{H}_{2} \mathrm{O}(1 \mathrm{~mL})$ was individually hydrolyzed with naringinase (10 mg, from Penicillium sp.; ICN Biomedicals Inc., Irvine, CA, USA) at $40{ }^{\circ} \mathrm{C}$ for $36 \mathrm{~h}$. Each reaction mixture was extracted with $\mathrm{CH}_{2} \mathrm{Cl}_{2}$ to yield the individual $\mathrm{CH}_{2} \mathrm{Cl}_{2}$ extract and a water phase. The $\mathrm{CH}_{2} \mathrm{Cl}_{2}$ extracts from compounds $\mathbf{1}$ and $\mathbf{2}$ were chromatographically separately with a Phenomenex Strata ${ }^{\circledR}$ C18-E column (2 g) using a gradient solvent system from $100 \% \mathrm{H}_{2} \mathrm{O}$ to $100 \%$ $\mathrm{MeOH}$ to give aglycones $\mathbf{1 a}(0.3 \mathrm{mg})$ and $\mathbf{2 a}(0.3 \mathrm{mg})$, respectively. The aglycone of $\mathbf{1 a}$ was determined to be (+)-secoisolariciresinol using LC/MS analysis with an $m / z$ signal of $361.2[\mathrm{M}-\mathrm{H}]^{-}$and a positive optical rotation $\left([\alpha]_{\mathrm{D}}^{25}+30.0, c 0.02\right.$, acetone) [16]. The CD spectrum of 1 a showed positive Cotton effects at 209, 223, and $288 \mathrm{~nm}$ and negative effects at 216 and $230 \mathrm{~nm}$. The aglycone of 2a was determined to be (+)-seco-5'-methoxy-isolariciresinol using LC/MS analysis with an $m / z$ signal of $393.2[\mathrm{M}+\mathrm{H}]^{+}$and a positive optical rotation $\left([\alpha]_{\mathrm{D}}^{25}+25.5, c 0.02\right.$, acetone $)$ [16]. After drying the water phase in vacuo, the residue was dissolved in anhydrous pyridine $(200 \mu \mathrm{L})$ followed by the addition of L-cysteine methyl ester hydrochloride $(0.6 \mathrm{mg})$. The reaction mixture was incubated at $60{ }^{\circ} \mathrm{C}$ for $1 \mathrm{~h}$, then $\mathrm{O}$-tolyl isothiocyanate $(15 \mu \mathrm{L})$ was added and the mixture was incubated at $60{ }^{\circ} \mathrm{C}$ for $1 \mathrm{~h}$. The reaction product was directly analyzed using LC/MS (0-35\% MeCN for $30 \mathrm{~min}$, flow rate: $0.3 \mathrm{~mL} / \mathrm{min})$ with an analytical Kinetex column $(2.1 \times 100 \mathrm{~mm}, 5 \mu \mathrm{m})$ (Agilent Technologies, Santa Clara, CA, USA). The L-rhamnose in compounds 1 and 2 was identified through comparison of the retention times with those of authentic sample $\left(t_{R}=\mathrm{L}\right.$-rhamnose $\left.25.6 \mathrm{~min}\right)$.

\subsection{Cytotoxicity Assay}

A sulforhodamine B (SRB) bioassay was used to determine the cytotoxicity of each isolated compound against four cultured human tumor cell lines [12,34]. The assays were performed at the Korea Research Institute of Chemical Technology. All the cell lines used, Bt549, MCF7, MDA-MB-231, and HCC70, are human breast cancer cells. Etoposide (purity $\geq 98 \%$, Sigma, St. Louis, MO, USA) was used as a positive control. The half maximal inhibitory concentrations $\left(\mathrm{IC}_{50}\right)$ of cancer cell growth are expressed as the mean from three distinct experiments.

\subsection{Antiviral Activity Assay}

Influenza A/PR/8 virus (PR8), human rhinovirus 1B (HRV1B), and coxsackievirus B3 (CVB3) were purchased from ATCC (American Type Culture Collection, Manassas, VA, USA). PR8, CVB3, 
and HRV1B were replicated in A549, Vero, and HeLa cells, respectively, at $37^{\circ} \mathrm{C}$. Antiviral activity was evaluated with the SRB method using cytopathic effect (CPE) reduction as previously reported [39].

\subsection{Oil Red OStaining}

At 6-8 days after differentiation, the adipocytes were fixed with $10 \%$ neutral buffered formalin (NBF) and stained with $0.5 \%$ Oil Red O (Sigma, St. Louis, MO, USA). To stop the reaction, cells were washed with distilled water three times. Stained cells were resolved with $1 \mathrm{~mL}$ of isopropanol and the colorimetric changes was measured at $520 \mathrm{~nm}$ to evaluate intra-cellular triglyceride content.

\subsection{Alkaline Phosphatase (ALP) Staining and Activity}

At 7-9 days after osteogenic differentiation, the medium was removed, and the cells were washed with $2 \mathrm{mM} \mathrm{MgCl}{ }_{2}$ solution. After incubation with AP buffer $(100 \mathrm{mM}$ Tris- $\mathrm{HCl}, \mathrm{pH} 9.5,100 \mathrm{mM} \mathrm{NaCl}$, and $10 \mathrm{mM} \mathrm{MgCl}$ ) for $15 \mathrm{~min}$, the cells were treated in AP buffer containing $0.4 \mathrm{mg} / \mathrm{mL}$ of nitro-blue tetrazolium (NBT, Sigma) and $0.2 \mathrm{mg} / \mathrm{mL}$ of 5-bromo-4-chloro-3-indolyl phosphate (BCIP, Sigma) for 15 more minutes. To stop the reaction, the cells were exposed to 5 mM EDTA (pH 8.0) and fixed with $10 \% \mathrm{NBF}$ for $1 \mathrm{~h}$.

The differentiation into osteoblast was evaluated regarding ALP activity. The ALP activity was determined using an Alkaline Phosphatase Assay Kit (ab83369; Abcam, Cambridge, MA, USA). Briefly, the cell lysates were incubated with $p$-nitrophenyl phosphate ( $p$-NPP) solution at RT for $1 \mathrm{~h}$ in the dark. After stopping the reaction, the optical density was measured at $405 \mathrm{~nm}$ using a SpectraMax M2/M2e Microplate Readers (Molecular Devices, San Jose, CA, USA).

\section{Conclusions}

In the present study, phytochemical analysis of the aerial portion of L. cuneata led to the isolation of two new lignan glycosides $(\mathbf{1}, \mathbf{2})$ along with three known lignan glycosides (3-7) and nine known flavonoid glycosides (8-14). All the isolated compounds were evaluated for their applicability for medicinal use using cell-based assays. Compounds $\mathbf{1}$ and 4-6 exhibited weak cytotoxicity against the breast cancer cell lines (Bt549, MCF7, MDA-MB-231 and HCC70) $\left(\mathrm{IC}_{50}<30.0 \mu \mathrm{M}\right)$, while none of the isolated compound showed significant antiviral activity against PR8, HRV1B, or CVB3. In a mouse mesenchymal stem cell line, treatment with compound $\mathbf{1 0}$ resulted in fewer lipid droplets compared to the untreated negative without altering the amount of alkaline phosphatase staining.

Supplementary Materials: Supplementary materials are available online. General experimental procedures, 1D NMR, 2D NMR, HRESIMS, CD data of $\mathbf{1}$ and 2, LC/MS analysis of $\mathbf{1}$ and 2, and Table S1 are available free of charge on the Internet.

Author Contributions: H.J.K., S.L. (Sanghyun Lee), S.-H.K. and K.H.K. conceived and designed the experiments; J.B., T.K.L., J.-H.S., E.C. and S.U.C. performed the experiments; H.-J.K., S.L. (Sanghyun Lee), S.H.K., S.U.C. and K.H.K. analyzed the data; S.L. (Seong Lee), S.-W.Y. and S.U.C. contributed reagents/materials/analysis tools; J.B., S.-H.K. and K.H.K. wrote the paper.

Funding: This work was supported by the National Research Foundation of Korea (NRF) grant funded by the Korea government (MSIT) (2018R1A2B2006879) and by the Ministry of Education (NRF-2012R1A5A2A28671860). This work was also supported by the Korea Institute of Planning and Evaluation for Technology in Food, Agriculture, Forestry, and Fisheries (iPET) through the Technology Commercialization Support Program, funded by the Ministry of Agriculture, Food, and Rural Affairs (MAFRA) (816004-02-1-SB010), Korea.

Conflicts of Interest: The authors declare no conflict of interest.

\section{References}

1. Kim, M.S.; Sharma, B.R.; Rhyu, D.Y. Beneficial effect of Lespedeza cuneata (G. Don) water extract on streptozotocin-induced type 1 diabetes and cytokine-induced beta-cell damage. Nat. Prod. Sci. 2016, 22, 175-179. [CrossRef]

2. Zhang, C.; Zhou, J.; Yang, J.; Li, C.; Ma, J.; Zhang, D.; Zhang, D. Two new phenylpropanoid glycosides from the aerial parts of Lespedeza cuneata. Acta Pharm. Sin. B 2016, 6, 564-567. [CrossRef] [PubMed] 
3. Min, J.Y.; Shim, S.H. Chemical constituents from Lespedeza cuneata G. Don (Leguminosae). Biochem. Syst. Ecol. 2016, 66, 293-296. [CrossRef]

4. Lee, H.; Jung, J.Y.; Hwangbo, M.; Ku, S.K.; Kim, Y.W.; Jee, S.Y. Anti-inflammatory effects of Lespedeza cuneata in vivo and in vitro. Korea J. Herbol. 2013, 28, 83-92. [CrossRef]

5. Zhang, C.F.; Zhou, J.; Yang, J.Z.; Li, C.J.; Ma, J.; Zhang, D.; Li, L.; Zhang, D.M. Three new lignanosides from the aerial parts of Lespedeza cuneata. J. Asian Nat. Prod. Res. 2016, 18, 913-920. [CrossRef] [PubMed]

6. Kim, S.M.; Kang, K.; Jho, E.H.; Jung, Y.J.; Nho, C.W.; Um, B.H.; Pan, C.H. Hepatoprotective effect of flavonoid glycosides from Lespedeza cuneata against oxidative stress induced by tert-butyl hyperoxide. Phytother. Res. 2011, 25, 1011-1017. [CrossRef] [PubMed]

7. Park, H.M.; Hong, J.H. Physiological activities of Lespedeza cuneata extracts. Korea J. Food Preserv. 2014, 21, 844-850. [CrossRef]

8. Deng, F.; Chang, J.; Zhang, J.S. New flavonoids and other constituents from Lespedeza cuneata. J. Asian Nat. Prod. Res. 2007, 9, 655-658. [CrossRef] [PubMed]

9. Zhou, J.; Li, C.J.; Yang, J.Z.; Ma, J.; Wu, L.Q.; Wang, W.J.; Zhang, D.M. Phenylpropanoid and lignan glycosides from the aerial parts of Lespedeza cuneata. Phytochemistry 2016, 121, 58-64. [CrossRef] [PubMed]

10. Jiang, W.; Ye, J.; Xie, Y.G.; Pan, Y.P.; Zheng, Y.; Qian, X.P.; Jin, H.Z. A new phenyldilactone from Lespedeza cuneata. J. Asian Nat. Prod. Res. 2016, 18, 200-205. [CrossRef] [PubMed]

11. Yoo, G.; Park, S.J.; Lee, T.H.; Yang, H.; Baek, Y.S.; Kim, N.; Kim, Y.J.; Kim, S.H. Flavonoids isolated from Lespedeza cuneata G. Don and their inhibitory effects on nitric oxide production in lipopolysaccharide-stimulated BV-2 microglia cells. Pharmacogn. Mag. 2015, 11, 651-656. [PubMed]

12. Yu, J.S.; Baek, J.; Park, H.B.; Moon, E.; Kim, S.Y.; Choi, S.U.; Kim, K.H. A new rearranged eudesmane sesquiterpene and bioactive sesquiterpenes from the twigs of Lindera glauca (Sieb. et Zucc.) Blume. Arch. Pharm. Res. 2016, 39, 1628-1634. [CrossRef] [PubMed]

13. Lee, D.; Kang, K.S.; Yu, J.S.; Woo, J.Y.; Hwang, G.S.; Eom, D.W.; Baek, S.H.; Lee, H.L.; Kim, K.H.; Yamabe, N. Protective effect of Korean Red Ginseng against FK506-induced damage in LLC-PK1 cells. J. Ginseng Res. 2017, 41, 284-289. [CrossRef] [PubMed]

14. Kim, S.; So, H.M.; Roh, H.S.; Kim, J.; Yu, J.S.; Lee, S.; Seok, S.; Pang, C.; Baek, K.H.; Kim, K.H. Vulpinic acid contributes to the cytotoxicity of Pulveroboletus ravenelii to human cancer cells by inducing apoptosis. RSC Adv. 2017, 7, 35297-35304. [CrossRef]

15. Baek, J.; Lee, D.; Lee, T.K.; Song, J.H.; Lee, J.S.; Lee, S.; Yoo, S.W.; Kang, K.S.; Moon, E.; Lee, S.; et al. (-)-9'-O-( $\alpha$-L-Rhamnopyranosyl)lyoniresinol from Lespedeza cuneata suppresses ovarian cancer cell proliferation through induction of apoptosis. Bioorg. Med. Chem. Lett. 2018, 28, 122-128. [CrossRef] [PubMed]

16. Sugahara, T.; Yamauchi, S.; Kondo, A.; Ohno, F.; Tominaga, S.; Nakashima, Y.; Kishida, T.; Akiyama, K.; Maruyama, M. First stereoselective synthesis of meso-secoisolariciresinol and comparison of its biological activity with (+) and (-)-secoisolariciresinol. Biosci. Biotechnol. Biochem. 2007, 71, 2962-2968. [CrossRef] [PubMed]

17. Li, W.; Koike, K.; Liu, L.; Lin, L.; Fu, X.; Chen, Y.; Nikaido, T. New lignan glucosides from the stems of Tinospora sinensis. Chem. Pharm. Bull. 2004, 52, 638-640. [CrossRef] [PubMed]

18. Kang, H.R.; Lee, D.; Benndorf, R.; Jung, W.H.; Beemelmanns, C.; Kang, K.S.; Kim, K.H. Termisoflavones A-C., isoflavonoid glycosides from termite-associated Streptomyces sp. RB1. J. Nat. Prod. 2016, 79, 3072-3078. [CrossRef] [PubMed]

19. Chen, X.; Zhu, Q. Pregnane glycoside, lignan glycosides, triterpene glycosyl ester and flavonoid glycosides from Rubus amabilis. Planta Med. 2001, 67, 270-273. [CrossRef] [PubMed]

20. Kim, C.S.; Subedi, L.; Kim, S.Y.; Choi, S.U.; Kim, K.H.; Lee, K.R. Lignan glycosides from the twigs of Chaenomeles sinensis and their biological activities. J. Nat. Prod. 2015, 78, 1174-1178. [CrossRef] [PubMed]

21. He, W.J.; Fu, Z.H.; Zeng, G.Z.; Zhang, Y.M.; Han, H.J.; Yan, H.; Ji, C.J.; Chu, H.B.; Tan, N.H. Terpene and lignan glycosides from the twigs and leaves of an endangered conifer, Cathaya argyrophylla. Phytochemistry 2012, 83, 63-69. [CrossRef] [PubMed]

22. Kil, Y.S.; Kim, S.M.; Kang, U.; Chung, H.Y.; Seo, E.K. Peroxynitrite-scavenging glycosides from the stem bark of Catalpa ovata. J. Nat. Prod. 2017, 80, 2240-2251. [CrossRef] [PubMed]

23. Tanaka, T.; Nakashima, T.; Ueda, T.; Tomii, K.; Kouno, I. Facile discrimination of aldose enantiomers by reversed-phase HPLC. Chem. Pharm. Bull. 2007, 55, 899-901. [CrossRef] [PubMed] 
24. Cho, H.K.; Suh, W.S.; Kim, K.H.; Kim, S.Y.; Lee, K.R. Phytochemical constituents of Salsola komarovii and their effects on NGF induction. Nat. Prod. Sci. 2014, 20, 95-101.

25. Rayyan, S.; Fossen, T.; Nateland, H.S.; Andersen, O.M. Isolation and identification of flavonoids, including flavone rotamers, from the herbal drug 'Crataegi folium cum flore' (hawthorn). Phytochem. Anal. 2005, 16, 334-341. [CrossRef] [PubMed]

26. Kim, D.K. Antioxidative constituents from the twigs of Vitex rotundifolia. Biomol. Ther. 2009, 17, $412-417$. [CrossRef]

27. Park, S.Y.; Kim, J.S.; Lee, S.Y.; Bae, K.H.; Kang, S.S. Chemical constituents of Lathyrus davidii. Nat. Prod. Sci. 2008, 14, 281-288.

28. Han, J.T.; Bang, M.H.; Chun, O.K.; Kim, D.O.; Lee, C.Y.; Baek, N.I. Flavonol glycosides from the aerial parts of Aceriphyllum rossii and their antioxidant activities. Arch. Pharm. Res. 2004, 27, 390-395. [CrossRef] [PubMed]

29. Yang, N.Y.; Tao, W.W.; Duan, J.A. Antithrombotic flavonoids from the faeces of Trogopterus xanthipes. Nat. Prod. Res. 2010, 24, 1843-1849. [CrossRef] [PubMed]

30. Lee, M.H.; Son, Y.K.; Han, Y.N. Tissue factor inhibitory flavonoids from the fruits of Chaenomeles sinensis. Arch. Pharm. Res. 2002, 25, 842-850. [CrossRef] [PubMed]

31. Chung, S.K.; Kim, Y.C.; Takaya, Y.; Terashima, K.; Niwa, M. Novel flavonol glycoside, 7-O-methyl mearnsitrin, from Sageretia theezans and its antioxidant effect. J. Agric. Food Chem. 2004, 52, 4664-4668. [CrossRef] [PubMed]

32. Kim, H.J.; Woo, E.R.; Park, H. A novel lignan and flavonoids from Polygonum aviculare. J. Nat. Prod. 1994, 57, 581-586. [CrossRef]

33. Torres-Mendoza, D.; González, J.; Ortega-Barría, E.; Heller, M.V.; Capson, T.L.; McPhail, K.; Gerwick, W.H.; Cubilla-Rios, L. Weakly antimalarial flavonol arabinofuranosides from Calycolpus warszewiczianus. J. Nat. Prod. 2006, 69, 826-828. [CrossRef] [PubMed]

34. Yao, C.J.; Chow, J.M.; Chuang, S.E.; Chang, C.L.; Yan, M.D.; Lee, H.L.; Lai, I.C.; Lin, P.C.; Lai, G.M. Induction of Forkhead Class box O3a and apoptosis by a standardized ginsenoside formulation, KG-135, is potentiated by autophagy blockade in A549 human lung cancer cells. J. Ginseng Res. 2017, 41, 247-256. [CrossRef] [PubMed]

35. Chung, S.T.; Huang, Y.T.; Hsiung, H.Y.; Huang, W.H.; Yao, C.W.; Lee, A.R. Novel daidzein analogs and their in vitro anti-influenza activities. Chem. Biodivers. 2015, 12, 685-696. [CrossRef] [PubMed]

36. Argenta, D.F.; Silva, I.T.; Bassani, V.L.; Koester, L.S.; Teixeira, H.F.; Simões, C.M. Antiherpes evaluation of soybean isoflavonoids. Arch. Virol. 2015, 160, 2335-2342. [CrossRef] [PubMed]

37. Zhang, T.; Wu, Z.; Du, J.; Hu, Y.F.; Liu, L.; Yang, F.; Jin, Q. Anti-Japanese-encephalitis-viral effects of kaempferol and daidzin and their RNA-binding characteristics. PLoS ONE 2012, 7, e30259. [CrossRef] [PubMed]

38. Sui, B.D.; Hu, C.H.; Zheng, C.X.; Jin, Y. Microenvironmental views on mesenchymal stem cell differentiation in aging. J. Den. Res. 2016, 95, 1333-1340. [CrossRef] [PubMed]

39. Song, J.; Yeo, S.G.; Hong, E.H.; Lee, B.R.; Kim, J.W.; Kim, J.; Jeong, H.; Kwon, Y.; Kim, H.; Lee, S.; et al. Antiviral activity of hederasaponin B from hedera helix against enterovirus 71 subgenotypes C3 and C4a. Biomol. Ther. 2014, 22, 41-46. [CrossRef] [PubMed]

Sample Availability: Samples of the compounds are not available from the authors. 